\title{
EFFECT OF SLAUGHTERING TECHNIQUES ON THE QUALITY OF FRESH "PATIN SIAM “ CATFISH (Pangasius hypopthalmus) STORED AT AMBIENT TEMPERATURE
}

\section{Pengaruh Teknik Mematikan terhadap Mutu Ikan Patin (Pangasius sp.) Segar yang Disimpan pada Suhu Kamar}

\author{
Diah Ikasari* and Th. Dwi Suryaningrum ${ }^{1}$ \\ ${ }^{1}$ Research and Development Center for Marine and Fisheries Product Processing and Biotechnology, \\ JI. K.S. Tubun Petamburan VI, Slipi, Central Jakarta 10260, Indonesia, *Correspondence Author: diah_ika263@yahoo.com \\ Article history: \\ Received: 10 April 2014; Revised: 18 Juli 2014; Accepted: 25 Juli 2014
}

\begin{abstract}
Fish handling is one of factors that affect fish quality deterioration, including slaughtering technique. In this study, the quality deterioration of fresh patin Siam catfish (Pangasius hypopthalmus) which were handled with different slaughtering techniques was observed. Fish were fasted for one day before slaughtered with two different techniques namely live-chilling and bleeding techniques. Live-chilling technique was conducted by exposing fish into cold water with temperature of $0-5^{\circ} \mathrm{C}$ for 15 minutes, while bleeding technique was conducted by cutting directly on the arteries part of fish head. After being slaughtered, fish were then stored at ambient temperatures for 18 hours and observed for its quality deterioration in every 3 hours. The observed parameters of fish quality deterioration were including the sensory attributes which were described using descriptive test by trained panelists; chemical parameters including proximate analysis; $\mathrm{pH}$ and Total Volatile Base (TVB), and microbiological parameters including Total Plate Count (TPC), coliform and E.coli. Results showed that the flesh of patin Siam catfish slaughtered by livechilling technique had more blood in the fish body tissue, while bleeding technique resulted in much brighter flesh as well as abdominal cavity. The flesh quality decreased after 18 hours of storage in both treatments, but no significant changes in their proximate values. Bleeding technique was more recommended compared to live-chilling technique for slaughtering patin Siam catfish due to its predominance in producing better flesh quality.
\end{abstract}

Keywords: Patin Siam catfish, slaughtering techniques, quality deterioration, bleeding technique, live-chilling technique

\begin{abstract}
ABSTRAK
Salah satu faktor yang mempengaruhi kemunduran mutu ikan adalah cara penanganannya, termasuk teknik mematikan ikan. Dalam penelitian ini telah diamati kemunduran mutu ikan patin Siam (Pangasius hypopthalmus) yang ditangani dengan menggunakan teknik mematikan yang berbeda. Ikan diberok selama satu hari kemudian dimatikan dengan menggunakan dua teknik yang berbeda yaitu direndam dalam air es dengan suhu $0-5^{\circ} \mathrm{C}$ selama 15 menit, dan teknik bleeding dengan memotong langsung arteri di bagian kepala ikan. Setelah dimatikan, ikan kemudian disimpan pada suhu kamar selama 18 jam dan dilakukan pengamatan terhadap kemunduran mutunya setiap 3 jam. Pengamatan dilakukan terhadap parameter sensori menggunakan uji descriptive oleh panelis terlatih; parameter kimia meliputi analisis proksimat, $\mathrm{pH}$ dan TVB; dan parameter mikrobiologi yang meliputi nilai Total Plate Count (TPC), coliform dan E.coli. Hasil penelitian menunjukkan bahwa ikan patin Siam yang dimatikan dengan teknik perendaman dalam air es menghasilkan kenampakan yang kurang menarik karena adanya darah di seluruh tubuh ikan, sedangkan teknik bleeding menghasilkan warna daging yang lebih cerah. Kualitas daging ikan mengalami penurunan setelah penyimpanan selama 18 jam pada kedua perlakuan, namun tidak berpengaruh nyata terhadap nilai proksimat ikan. Teknik bleeding lebih disarankan dalam penanganan ikan patin Siam dibandingkan teknik perendaman dalam air es karena menghasilkan daging ikan patin dengan kualitas yang lebih baik.
\end{abstract}

Kata Kunci: ikan patin siam, teknik mematikan, kemunduran mutu, teknik bleeding, teknik perendaman air es 


\section{Introduction}

Patin catfish is one of potential fish due to its economic value, easily cultivated, and highly resistant to disease. Some countries such as Spain, U.K, Netherland, Poland and France are the biggest catfish consumer by importing $46,9 \%$ of world's total catfish production volume (Anon., 2009a). In 2009, patin catfish is one of the most consumed fish in United States (Ditjen PEN, 2013). The consumer's preference to patin catfish is mostly due to its good taste, good quality and high availability in the market. The consumer demand of Patin catfish in the global market is commonly in the form of fillets which popular with the name of "dory fillets".

Indonesia has potency in producing and exporting patin catfish since the fish has been cultured in many regions including West Java, South Sulawesi, Jambi, Riau, Bengkulu, Lampung and Kalimantan (Ditjen PEN, 2013). There are 4 varieties of patin catfish, including patin Siam, Jambal, Nasutus and Pasupati, which is the hybrid of patin Siam and Jambal. Production of patin catfish in Indonesia reaches to 651,000 tons in 2012 which was dominated by patin Siam (Pangasius hypopthalmus) (Anon., 2009a). However, this high production is not followed by advanced technologies in terms of harvesting, handling and processing to produce good quality products. Processing of patin catfish into fillet would have higher added value and higher consumer acceptability. As a comparison, the price of whole fresh patin catfish was 1 USD per $\mathrm{kg}$, while the price of patin catfish fillet reached to 3.4 USD per kg (Ditjen PEN, 2013). Recently, Indonesia is still importing patin catfish fillets from Vietnam. Vietnam has become the biggest exporting country of patin catfish fillet with 65 countries of destination (Anon., 2009b).

The quality of fish fillet can be determined from its appearance, texture, taste, chemical constituent and food safety (Robb, 2010). According to U.S Grade Standards for fish fillet (U.S Departement of Commerce, 1979), fish fillet can be categorized as grade $A$ when it possess good flavour and odor characteristic of the species, and comply with the limits for defects for U.S Grade A quality in accordance with the established Grade Determination. The defects are including physical and chemical structure of fish flesh, colour and degree of surface dehydration of fillets, cutting and trimming imperfections, the present of bone and skin, and the texture of the cooked fillets (U.S Departement of Commerce, 1979). The quality of fish fillets is mainly determined during primary processing of fish based on the influence of catching, slaughtering, bleeding, gutting, washing, and filleting (Border'ýas \& Isabel, 2010).
One of factors that are considered to have the significant effect on the quality of patin catfish fillet is slaughtering technique during handling of the fresh fish. Different slaughtering technique is believed to induce different metabolism process during pre-rigor, rigor and post rigor which are associated to the fish welfare. Several quality parameters changes are affected by the slaughtering condition and by stress severity (Poli, Parisi, Scappini, \& Zampacavallo, 2005). Live-chilling method has been commonly used in fish handling, conducted by rapidly decreasing the fish metabolic rate, movement and the oxygen requirements, thus the time to die would be prolonged. This technique is believed to be effective in maintaining the freshness of the fish. Moreover, low temperature can inhibit the growth of microorganisms and other biochemical processes that occur in fish body, inhibiting deterioration process (Gelman, Glatman, Drabkin, \& Harpaz, 2001). The common application of low temperature technique is using water with ice slurry. Ice has some advantages for fish handling including higher capacity, safe to consumer, easy to use; and inexpensive (Ilyas, 1993; Emanuela, Egidio, Sergio, \& Adriana, 2010). However, research conducted in rainbow trout showed that killing the fish by exposing in ice does not result in immediate unconsciousness, causing fish stress, and affected the fish flesh color and texture (Lefevre et al., 2008; Robb \& Kestin, 2002). The other technique called bleeding technique is commonly used for large fish. The gills are cut or pull out and then the fish are returned to water to bleed for period of 10 to 15 minutes (Wardle, 1997; Emanuela et al., 2010). Research conducted to rainbow trout showed that better quality of fish flesh was obtained by the bleeding technique because the fish experienced an instant death without being exposed to longer stress (Emanuela et al., 2010). However, study on the effect of slaughtering technique to the quality of patin catfish is still limited. This study was aimed to investigate the effect of different slaughtering techniques on the quality deterioration of patin Siam catfish (Pangasius hypopthalmus) during storage at ambient temperature. This study will provide the best technique for handling patin Siam in order to produce high quality product.

\section{Materials and Methods}

\subsection{Materials}

Total of 42 live patin Siam catfish (Pangasius hypopthalmus) which had $500-700 \mathrm{~g}$ weight/individual; $39-45 \mathrm{~cm}$ total length; $32-37 \mathrm{~cm}$ body length; $6.2-8.1$ $\mathrm{cm}$ body width; and $3-4.1 \mathrm{~cm}$ body thickness. The fish was obtained from Parung, Bogor, Indonesia. Ice blocks were crushed and mixed with water to make live-chilling media at $0-5^{\circ} \mathrm{C}$. 


\subsection{Methods}

Fish were fasted for a day before slaughtered (Hastarini, 2007). Slaughtering was performed using two different techniques, namely live-chilling and bleeding techniques. Live-chilling method was done by exposing fish into cold water at $0-5{ }^{\circ} \mathrm{C}$ for 15 minutes (Poli, Parisi, Scappini, \& Zampacavallo, 2005). Bleeding method was conducted by cutting directly on the arteries part of fish head and then the blood was drained by hanging the fish upside down for 10 minutes (Wardle, 1997). The fish were then stored at ambient temperature $\left(27.6-28.6^{\circ} \mathrm{C}\right)$ for 18 hours and observed for its quality parameters every 3 hours $(0,3,6,9,12,15,18$ hours). The experiment was run in triplicates.

The quality parameters being observed were including sensory attributes, moisture content (BSN, 2006a), pH (AOAC, 2005), Total Volatile Base (TVB) (Conway method) (AOAC, 2005) and Total Plate Count (TPC) (BSN, 2006b) during 18 hours storage. The sensory attributes were evaluated by descriptive test, conducted by 6 trained panellists who had been selected from panellist training on fresh fish using 3 methods, namely triangle, pair comparison and duo trio tests. The procedure of panellist training and selection were referred to American Society for Testing and Materials (ASTM)(1968), while the score sheet on fresh fish attributes was referred to BSN (2006c).

The samples for sensory evaluation were prepared both as fresh and cooked samples. The fresh samples were presented as whole patin Siam catfish, while the cooked samples were prepared by filleting the fish with dimension of $0.9-1.2 \mathrm{~cm}$ thickness, wrapping the fillet with aluminum foil of $450 \mathrm{~mm}$ thickness and then steamed at $100^{\circ} \mathrm{C}$ for 15 minutes. The sensory attributes being tested were including appearance, texture, odor and stiffness. Other parameters were proximate composition (at the beginning and end of experiment) including ash content (BSN, 2006d), protein content (BSN, 2006e), and fat content (BSN, 2006f), as well as microbiological indices consisting of coliform and E. coli (BSN, 2006g). All parameters were analysed in triplicates. The data were then statistically analysed using PASW Statistics 18 programme. Flow chart of the experiment on the quality deterioration of patin Siam catfish is presented in Figure 1.

\section{Results and Discussion}

\subsection{Sensory Attributes Changes}

The sensory test was conducted using a descriptive test which was mainly focused on the changes of attributes during pre-rigor and rigor periods. During 18 hours of storage at ambient temperature, the fish exhibited some changes which were marked by the emerging of mucus, discoloration of abdominal cavity, and unpleasant odor. Results of sensory test on patin siam catfish during 18 hours storage at ambient temperature were presented in Table 1 and 2.

According to the results of descriptive test, different slaughtering techniques affected to the quality attributes of patin Siam catfish both in fresh and cooked condition, especially in the flesh appearance (Figure 2). In terms of fresh fish, live-chilling technique produced more blood in the tissue of many fish body part, such as abdominal cavity and fish flesh. It is believed that rapid temperature decrease can induce stress to the fish because of high temperature change in a short time. This occurrence affects fish metabolic rate and movements, bringing about the crack of blood vessel which eventually affects flesh color. In addition, rapid temperature decrease also means marked decrease of oxygen requirement, causing fish mortality due to anoxia (Poli et al., 2005).

Whereas in bleeding technique, the fish exhibited an immediate death due to the direct cutting of blood vessel in lower part or main artery of fish head. The blood did not contaminate other fish body parts because the blood was released from fish body during draining, resulting in much brighter flesh and abdominal cavity.

According to Lefevre et al. (2008), both color and texture are affected by the stress during slaughtering process. Fish subjected to a minimal stress would result in a significant decrease in lightness of fillet compared to the stressed one. Therefore, controlling of stress during slaughtering process to a minimum level is important to keep the highest quality of the product (Emanuela et al., 2010). Fish should be killed without any unnecessary stress through operation based on practical issues (Parisi et al., 2002; Poli et al., 2002; Zampacavallo et al., 2003; Poli et al., 2005).

The experiment showed that there was a significant different found in the texture of fresh fish slaughtered by different techniques during 18 hours storage at ambient temperature. The texture of fresh fish flesh was elastic, compact and dense at the beginning of storage. After 18 hours storage under ambient temperature $\left(25-30^{\circ} \mathrm{C}\right)$ fish were observed to indicate quality deterioration in both treatments. This phenomenon showed by the decrease of the sensory score with time of storage. Mucus was found in fresh fish after 6 hours storage and became thicker after 9 hours storage. In addition, fish were also duller in color at this period of storage. The fish rectum was broken 


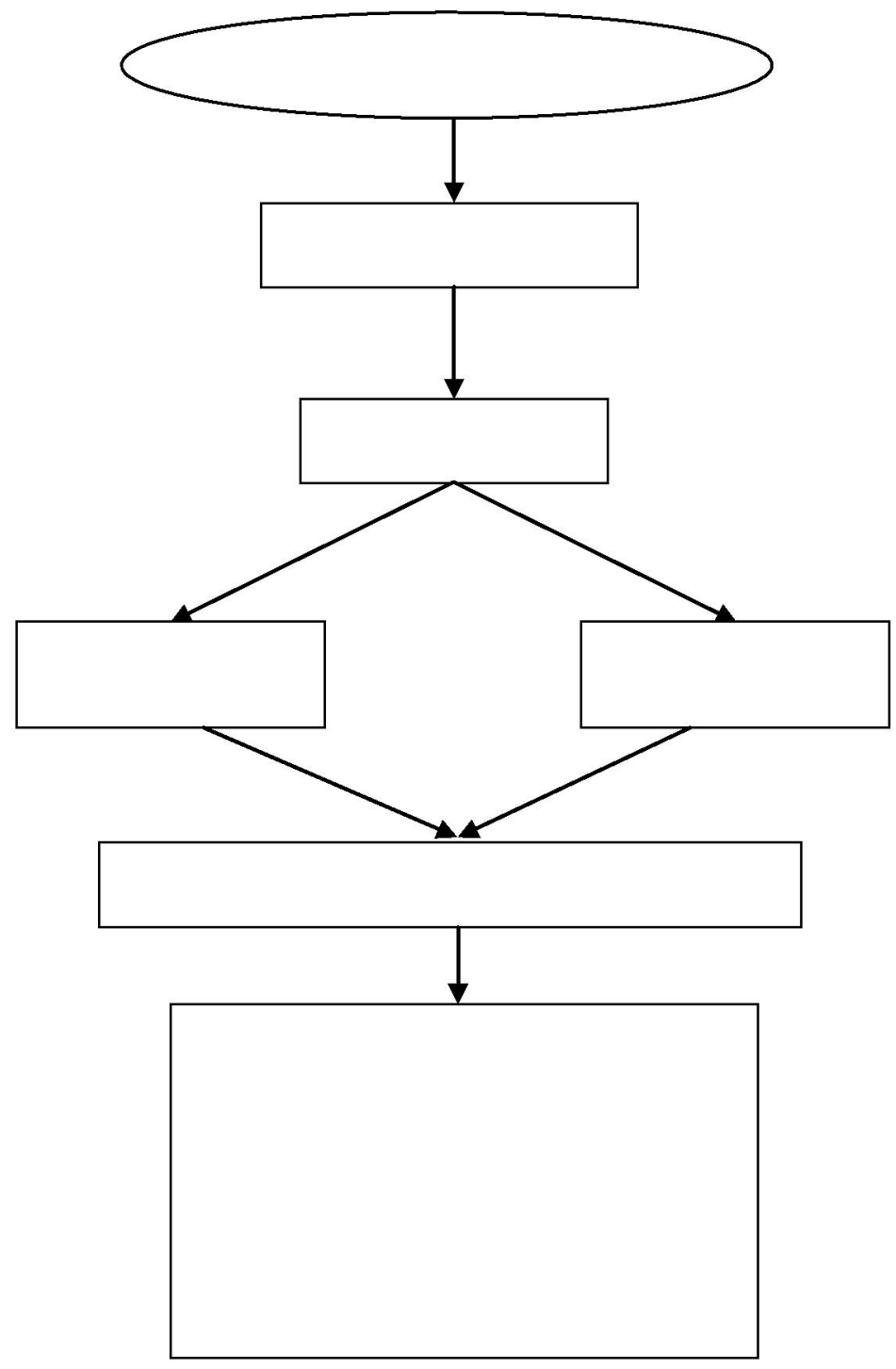

Figure 1. Flow chart of the patin siam catfish quality deterioration experiment.

Table 1. Descriptive test of fresh patin Siam catfish after killed with different slaughtering techniques during 18 hours storage at ambient temperature

\begin{tabular}{|c|c|c|}
\hline \multirow[t]{2}{*}{ Time of observation } & \multicolumn{2}{|c|}{ Attribute changes of fresh patin Siam catfish } \\
\hline & Live-chilling & Bleeding \\
\hline 0 hour & & \\
\hline 1. Appearance & & \\
\hline - Flesh color & Yellowish & Yellowish \\
\hline - Eye & Normal & Normal \\
\hline - Skin & No changes & No changes \\
\hline - Gills & Fresh, bright red color & Fresh bright red color \\
\hline - Abdominal cavity & Bleeding & Not bleding \\
\hline - Rectum & Normal & Normal \\
\hline
\end{tabular}


Squalen Bulletin of Marine \& Fisheries Postharvest \& Biotechnology, 9 (2), 2014, 63-74

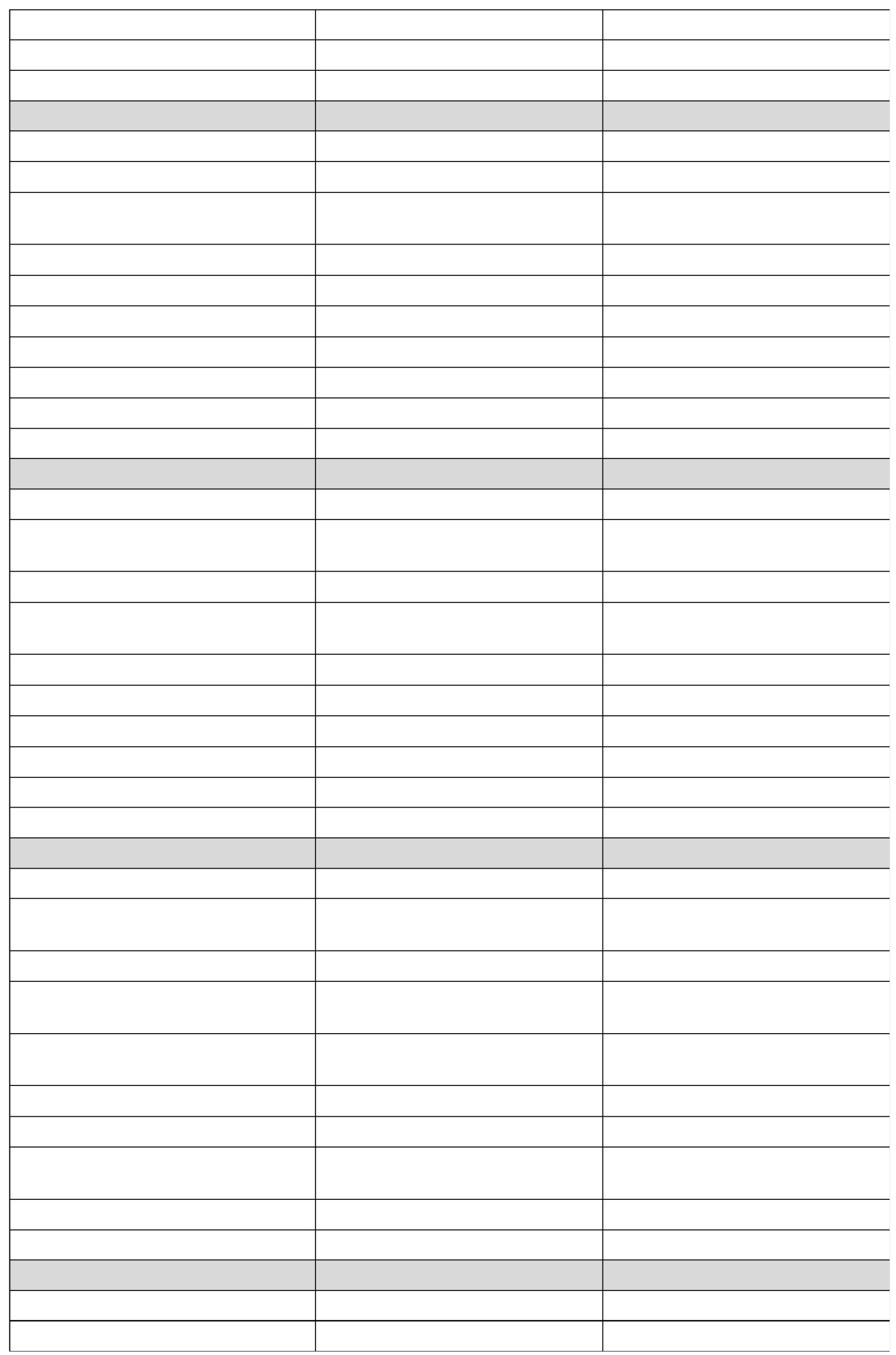


Squalen Bulletin of Marine \& Fisheries Postharvest \& Biotechnology, 9 (2), 2014, 63-74

\begin{tabular}{|l|l|l|}
\hline & & \\
\hline & & \\
\hline & & \\
\hline & & \\
\hline & & \\
\hline & & \\
\hline & & \\
\hline & & \\
\hline & & \\
\hline & & \\
\hline & & \\
\hline & & \\
\hline & & \\
\hline & & \\
\hline & & \\
\hline & & \\
\hline & & \\
\hline & & \\
\hline & & \\
\hline & & \\
\hline & & \\
\hline & & \\
\hline & & \\
\hline & & \\
\hline & & \\
\hline & & \\
\hline & & \\
\hline & & \\
\hline & & \\
\hline & & \\
\hline & & \\
\hline & & \\
\hline & & \\
\hline & & \\
\hline & & \\
\hline & & \\
\hline & & \\
\hline & & \\
\hline
\end{tabular}

Table 2. Descriptive test of cooked patin Siam catfish after killed with different slaughtering techniques during 18 hours storage at ambient temperature

\begin{tabular}{|l|l|l|}
\hline \multirow{2}{*}{} & & \\
\cline { 2 - 3 } & & \\
\hline & & \\
\hline & & \\
\hline & & \\
\hline & & \\
\hline & & \\
\hline & & \\
\hline & & \\
\hline & & \\
\hline
\end{tabular}




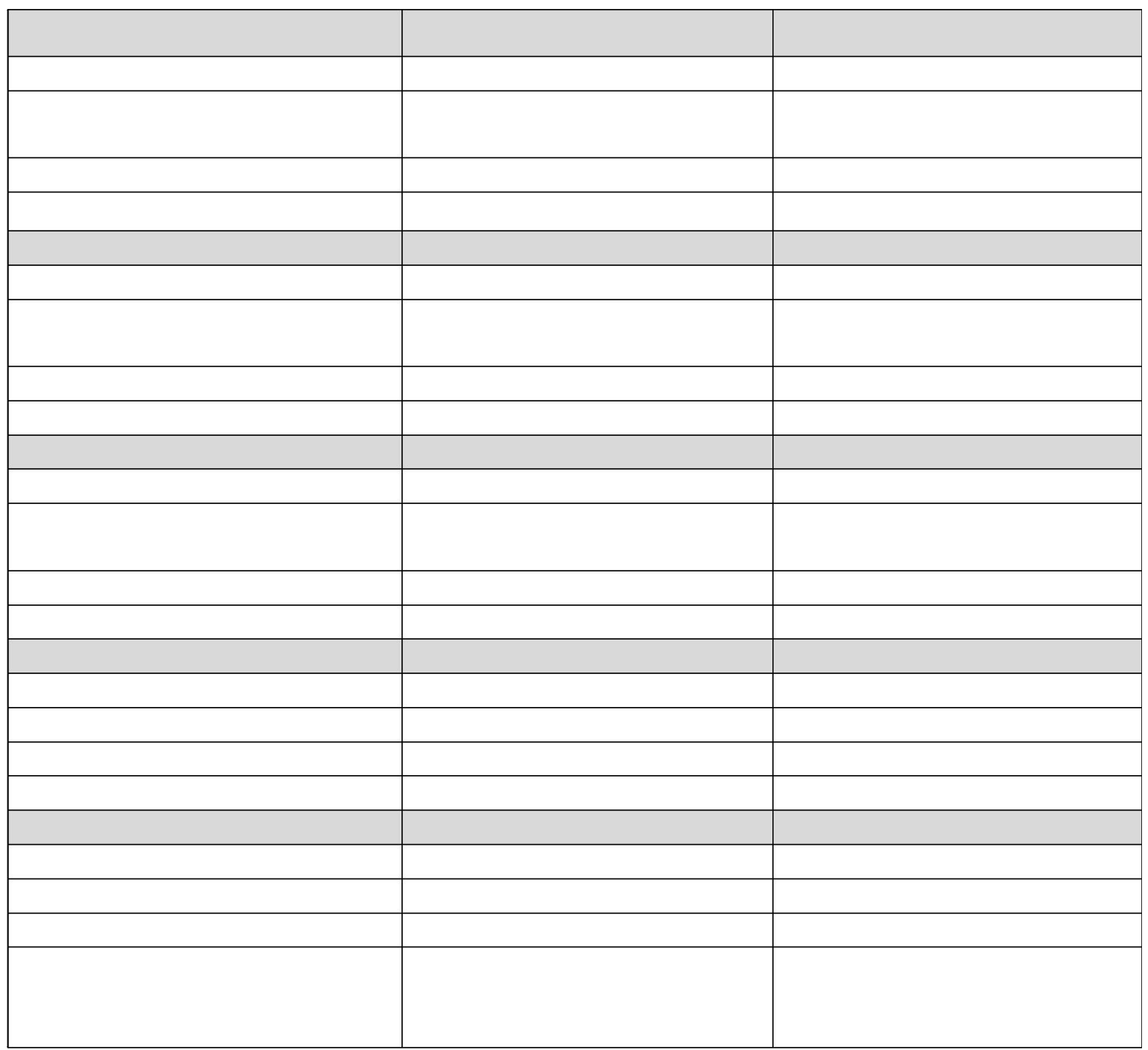

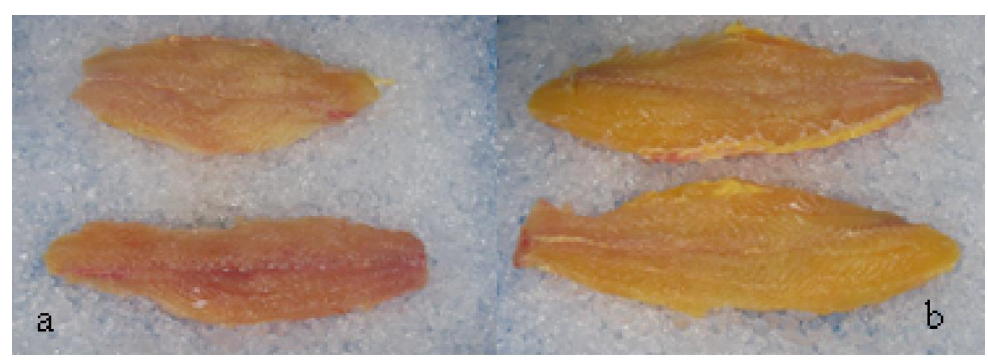

Figure 2. Fillets of patin Siam catfish killed with different slaughtering method: (a) live-chilling method; (b) bleeding method.

and produced a strong off odor after 12 hours storage. More severe deterioration characteristics were detected after 18 hours storage including dull flesh color, mushy skin texture, thick mucus on the surface, body stiffness, eyes covered with mucus, concave eye balls, dissapeared pupil, blood on the tissues, darker gills with thick mucus, strong off odor, discoloration on the abdominal cavity, broken rectum, and watery texture.

The sensory attributes performance in cooked fish at the beginning of storage were also identified to be significantly different compared to the performance at the end of storage. At the beginning of storage, the cooked flesh had white color, compact and dense 
texture as well as good taste; while at the end of storage (18 hours) the cooked flesh color became creamy brown, mushy, smell like steamed fish as well as unacceptable taste and muddy flavor. Those facts occurred in both treatments, either using live-chilling or bleeding techniques. According to Papa et al. (1996), during the first 24 hours of ice storage, a key component of muscle which is connecting to neighboring-sarcomeres called as a-actinin was rapidly released, inducing a looser and softer texture.

\subsection{Chemical Parameters Changes}

Moisture content of patin Siam catfish fluctuated during storage, ranging from 77 to $82.5 \%$. Moisture content of live chilled fish was significantly higher compared to the moisture content of fish slaughtered by bleeding technique $(p<0.05)$. This is possibly contributed by water from slurry ice used as a medium in live-chilling technique.

The analysis of TVB is aimed to determine the freshness of the fish. The result indicated that TVB value of fish tended to increase significantly at 15 and 18 hours storage $(p<0.05)$ (Figure 3$)$. Higher value of TVB indicates lower level of fish freshness. This study showed that the longer the storage of fish, the more fish was deteriorated. The storage of fish under ambient temperature has accelerated the deterioration process (Magnússon \& Martinsdóttir, 1995).

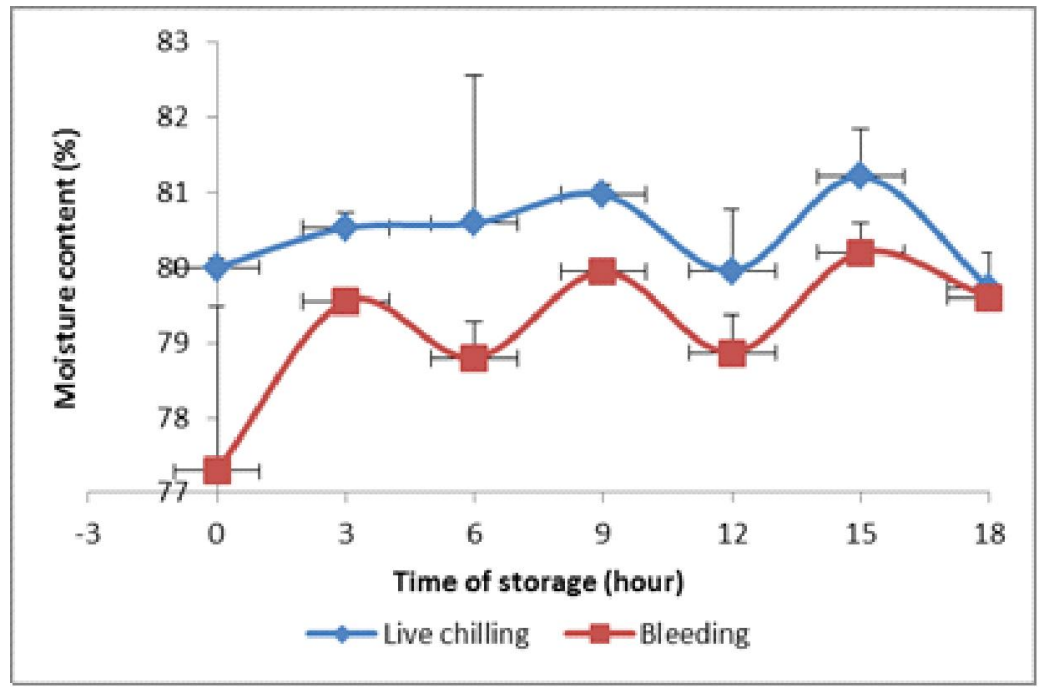

Figure 3. Moisture content of patin Siam catfish killed with different slaughtering techniques during 18 hours storage at ambient temperature.

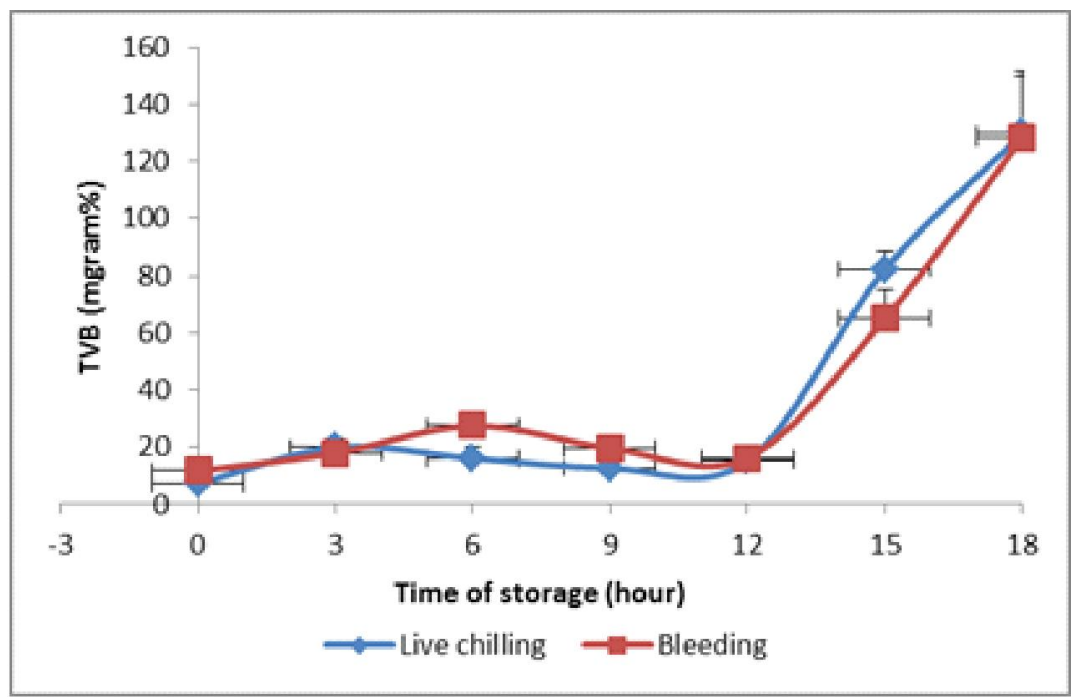

Figure 4. TVB value of patin Siam catfish after killed with different slaughtering techniques during 18 hours storage at ambient temperature. 
The $\mathrm{pH}$ values of patin Siam catfish fluctuated through the storage, ranging from 6.47 to 6.78 (Figure 4). According to Poli et al. (2005), $\mathrm{pH}$ of fresh fish is around 6.5. $\mathrm{pH}$ values is believed to have a correlation with slaughtering methods, which is eventually affecting the physical properties of flesh. A stressful slaughtering method will cause exhausted muscular energies, lactic acid production, muscular $\mathrm{pH}$ reduction and increasing rate of rigor mortis onset, thus having a negative effect on flesh quality (Poli et al., 2005). However, based on the results, the $\mathrm{pH}$ values of fish slaughtered with live-chilling technique were insignificantly different from $\mathrm{pH}$ values of fish slaughtered with bleeding technique $(p>0.05)$. In addition, storage time tends to increase the $\mathrm{pH}$ values which can be associated with the production of basic components due to the growth of bacteria (Simeonidou, Govans, \& Vareltzis, 1998; Arannilewa, Salawu, Sorungbe, \& Ola-Salawu, 2005). However, this trend was not identified in this experiment since the $\mathrm{pH}$ values fluctuated.

Moreover, analyses of proximate composition of patin Siam catfish at the beginning and end of experiment were conducted to demonstrate the changes of proximate value of patin catfish before and after 18 hours storage at ambient temperature. Proximate composition of patin Siam catfish is presented in Table 3.

Table 3 showed that there was a decreasing trend of ash content, protein content and fat content during 18 hours storage of fish. However, statistically, the decrease was insignificantly different $(p>0.05)$. That fact indicated that the proximate value of patin Siam catfish did not correlate to the quality deterioration. Although patin Siam catfish exhibited quality deterioration after 18 hours storage, particularly reflected by the dramatically increase of TVB values, the proximate value of the fish was not significantly affected.

\subsection{Microbiological Parameters}

Total plate count of the flesh samples showed a positive correlation with storage time. The total bacteria count of fish flesh increased with the time of storage. The total bacteria count in fish flesh during storage is presented in Table 4.

Live-chilling technique resulted in higher total bacteria count in the fish compared to bleeding technique since the beginning of storage. This was probably caused by the effect of the blood draining during slaughtering process. In the bleeding technique, the blood was removed from fish body by hanging the fish upside down for 10 minutes. In contrast, livechilling technique killed the fish without removing the blood from fish body. According to Schmidt (2013), all products containing blood components are major source of bacterial contamination especially when it is stored under ambient temperature.

The total bacteria count increased to $10^{7} \mathrm{cfu} / \mathrm{ml}$ after 12 hours storage and dramatically increased after 18 hours storage. This result indicates that bacteria play an important role during the deterioration process of the fish. This indication was in accordance with the result of sensory evaluation in which the deterioration process started after 18 hours storage, characterized by off-odor, mushy texture, and the presence of thicker mucus.

Moreover, total coliform was identified to $<3,0 \mathrm{cfu} /$ $\mathrm{ml}$ in average while E.coli was found to be negative.

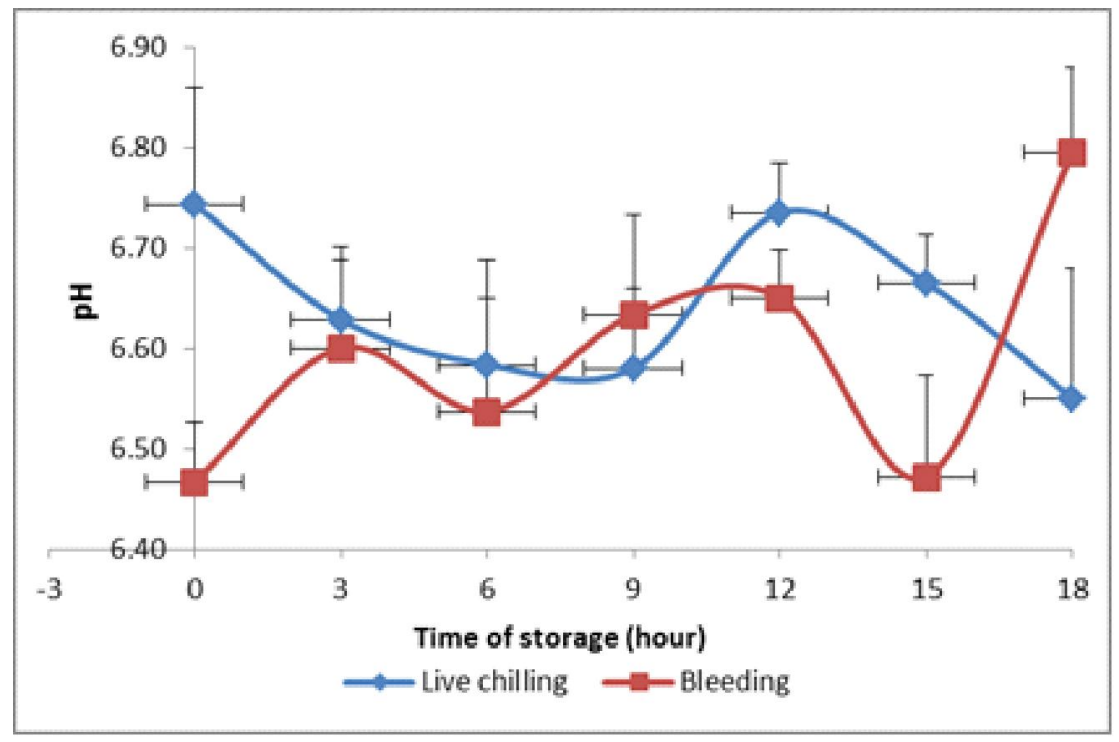

Figure 5. $\mathrm{pH}$ values of patin Siam catfish during 18 hours storage 
Table 3. Proximate composition of patin Siam catfish based on dry basis from two slaughtering techniques and stored at ambient temperature for 18 hours

\begin{tabular}{lcccc}
\hline & \multicolumn{2}{c}{ Live-chilling } & \multicolumn{2}{c}{ Bleeding } \\
\cline { 2 - 5 } & $\mathbf{0}$ hour (\%) & $\mathbf{1 8}$ hours (\%) & 0 hour (\%) & $\mathbf{1 8}$ hours (\%) \\
\hline Ash content & $1.40 \pm 0.04^{\mathrm{a}}$ & $1.29 \pm 0.04^{\mathrm{a}}$ & $1.45 \pm 0.18^{\mathrm{a}}$ & $1.32 \pm 0.01^{\mathrm{a}}$ \\
Protein content & $20.83 \pm 1.61^{\mathrm{a}}$ & $20.65 \pm 0.95^{\mathrm{a}}$ & $22.02 \pm 1.60^{\mathrm{a}}$ & $21.53 \pm 1.48^{\mathrm{a}}$ \\
Fat content & $1.46 \pm 0.45^{\mathrm{a}}$ & $1.09 \pm 0.09^{\mathrm{a}}$ & $0.87 \pm 0.16^{\mathrm{a}}$ & $0.71 \pm 0.26^{\mathrm{a}}$ \\
\hline
\end{tabular}

Table 4. Total bacteria content of patin Siam catfish from two different slaughtering techniques during 18 hours storage

\begin{tabular}{cccccccc}
\hline & \multicolumn{6}{c}{ Total Plate Count (CFU/ml) } \\
\cline { 2 - 7 } & $\mathbf{0 ~ h}$ & $\mathbf{3 h}$ & $\mathbf{6 ~ h}$ & $\mathbf{9 h}$ & $\mathbf{1 2} \mathbf{h}$ & $\mathbf{1 5} \mathbf{h}$ & $\mathbf{1 8 ~ h}$ \\
\hline Live-chilling & $1.87 \times 10^{5}$ & $3.1 \times 10^{5}$ & $7.6 \times 10^{3}$ & $9.8 \times 10^{5}$ & $3.46 \times 10^{7}$ & $5.13 \times 10^{7}$ & $22.9 \times 10^{7}$ \\
Bleeding & $25 \times 10^{2}$ & $4.7 \times 10^{3}$ & $17.5 \times 10^{3}$ & $1.43 \times 10^{6}$ & $1.8 \times 10^{7}$ & $5 \times 10^{7}$ & $5.03 \times 10^{7}$ \\
\hline
\end{tabular}

Table 5. Coliform and E.coli content of patin Siam catfish at the beginning of storage

\begin{tabular}{lcc}
\hline & \multicolumn{2}{c}{ Parameters } \\
\cline { 2 - 3 } & Coliform (CFU/ml) & E. coli (CFU/ml) \\
\hline Live-chilling & 3.0 & 0 \\
Bleeding & 3.0 & 0 \\
\hline
\end{tabular}

The results of coliform and E.coli tests of patin Siam catfish are presented in Table 5 . The coliform count may indicate faecal contamination from the contaminated water or from the evisceration process (Boulares, Mejri, \& Hassouna, 2011). Therefore, the result of coliform test in this study indicated that the handling process of patin Siam catfish during pre and post slaughtering process was quite hygienic with acceptable quality of raw material for consumption. Pathogens usually are present in fresh fish in small numbers, but they can be introduced into foods during processing from the air, unclean hands, unsanitary equipment, and unsafe water (US FDA, 2001; Ligia et al., 2008).

\section{Conclusion}

Based on the above explanation, it can be concluded that the quality deterioration of fresh patin Siam catfish (Pangasius hypopthalmus) was influenced by the slaughtering technique during handling. Live-chilling technique produced more blood in the tissue in many part of fish body, while bleeding technique yielded brighter flesh as well as abdominal cavity. The flesh quality from both slaughtering techniques decreased after 18 hours storage. Overall, bleeding technique was more recommended to be implemented compared to live-chilling technique for slaughtering patin Siam catfish.

\section{References}

AOAC. (2005). Official Methods of Analysis of The Association of Official Analytical Chemist. Inc. Washington. DC.

Anonymous. (2009a). Patin, Ikan Paling Kontroversial. Warta Perikanan, 74, 18-19.

Anonymous. (2009b). Kreativitas Vietnam untuk Patin. Warta Perikanan, 71, 8-10.

Arannilewa, S. T, Salawu, S. O, Sorungbe, A. A., \& OlaSalawu, B. B. (2005). Effect of frozen period on the chemical, microbiological and sensory quality of 
frozen tilapia fish (Sarotherodun galiaenus). African Journal of Biotechnology, 4(8): 852-855.

ASTM (American Society for Testing and Materials). (1968). Manual on Sensory Testing Methods. ASTM, Philadelphia. 78pp.

Border'ýas, A. J \& Isabel, S. (2010). First processing steps and the quality of wild and farmed fish. Journal of Food Science, 76(1): R1-R5. Retrieved at December $15^{\text {th }}, 2014$ from http://onlinelibrary. wiley.com/doi/10.1111/j.1750-3841. 2010. 01900.x/ pdf.

BSN (Badan Standardisasi Nasional). (2006a). Cara Uji Kimia-Bagian 2: Penentuan Kadar Air pada Produk Perikanan. SNI 01-2354.2-2006. Standar Nasional Indonesia.

BSN (Badan Standardisasi Nasional). (2006b). Cara Uji Mikrobiologi-Bagian 3: Penentuan Angka Lempeng Total (ALT) pada Produk Perikanan. SNI 01-2332.32006. Standar Nasional Indonesia.

BSN (Badan Standardisasi Nasional). (2006c). Petunjuk Pengujian Organoleptik dan atau Sensori. SNI 012346-2006. Standar Nasional Indonesia.

BSN (Badan Standardisasi Nasional). (2006d). Cara Uji Kimia-Bagian 1: Penentuan Kadar Abu pada Produk Perikanan. SNI 01-2354.1-2006. Standar Nasional Indonesia.

BSN (Badan Standardisasi Nasional). (2006e). Cara Uji Kimia-Bagian 4: Penentuan Kadar Protein dengan Metode Total Nitrogen pada Produk Perikanan. SNI 01-2354.4-2006. Standar Nasional Indonesia.

BSN (Badan Standardisasi Nasional). (2006f). Cara Uji Kimia-Bagian 3: Penentuan Kadar Lemak Total pada Produk Perikanan. SNI 01-2354.3-2006. Standar Nasional Indonesia.

BSN (Badan Standardisasi Nasional). (2006g). Cara Uji Mikrobiologi-Bagian 1: Penentuan Coliform dan Escherichia coli pada Produk Perikanan. SNI 012332.1-2006. Standar Nasional Indonesia.

Boulares, M., Mejri, L. \& Hassouna, M. (2011). Study of the microbial ecology of wild and aquacultured Tunisian fresh fish. Journal of Food Protection, 74(10):1762-1768.

Ditjen PEN. (2013). Ikan patin hasil alam bernilai ekonomi dan berpotensi ekspor tinggi. Retrieved at March $5^{\text {th }}, 2014$ from http://djpen.kemendag.go.id/ app_frontend/webroot/admin/docs/publication/ 8241384233598.pdf.

Emanuela, Z., Egidio, S., Sergio, G. \& Adriana, I. (2010). The effects of slaughtering methods of rainbow trout on animal welfare and fish quality : recent advances. Ann. Fac. Medic. Vet. Di Parma, XXX : 81-90.

Gelman, A., Glatman, L., Drabkin, V. \& Harpaz, S. (2001). Effect of storage temperature and preservative treatment on shelf life of the pond-raised freshwater fish, silver perch (Bidyanus bidyanus). Journal Food Protection, 64: 1584-1591.

Hastarini, E., Lestari, D.A, . (2007). Technical Report. Research on the Development of Surimi based
Products. Research Center for Marine and Fisheries Product Processing and Biotechnology. Jakarta.

llyas, S. (1993). Referigeration technique of fisheries products, $1^{\text {st }}$ ed., Fish Cooling technique. CV. Paripurna, Jakarta.

Lefevre, F., Bugeon, J., Auperin, B. \& Aubin J. (2008) Rearing oxygen level and slaughter stress effects on rainbow trout flesh quality. Aquaculture, 284: 81-89

Ligia, A. S., Prinyawiwatkul, W., King, J. M., Kyoon, H., Bankston, J. D. \& Ge, B. (2008). Effect of preservatives on microbial safety and quality of smoked blue catfish (Ictalurus furcatus) steaks during room-temperature storage. Food Microbiol.,8:958-963.

Magnusson, H \& Martinsdottir, E. (1996). Storage quality of fresh and frozen-thawed fish in ice. Journal of Food Science, 60(2): 273-278.

Papa, I., Alvarez, C., Verrez-Bagnis, V., Fleurence, J., \& Benyamin, Y. (1996). Post mortem release of ûsh white muscle alpha-actinin as a marker of disorganisation. Journal of the Science of Food and Agriculture, 72, 63-70.

Parisi, G., Mecatti, M., Lupi, P., Scappini, F. \& Poli, B.M. (2002). Comparison of ûve slaughter methods for European sea bass. Changes of isometric contraction force and $\mathrm{pH}$ during the ûrst 24 hours post mortem. In: Proceedings of the "Aquaculture Europe 2002: Sea Farming Today and Tomorrow". Special Publication n. 32, pp.417-418.

Poli, B.M., Zampacavallo, G., Iurzan, F., de Francesco, M., Parisi, G. \& Mosconi, G. (2002). Biochemical stress indicators changes in sea bass as inûuenced by the slaughter method. In: Proceeding of the "Aquaculture Europe 2002: Sea Farming Today and Tomorrow". Special Publication n. 32, pp. 429-430.

Poli, B. M., Parisi, G., Scappini, F. \& Zampacavallo, G. (2005) Fish welfare and quality as affected by preslaughter and slaughter management. Aquaculture International, 13, 29-49.

Robb, D.H.F. \& Kestin, S.C. (2002). Methods used to kill fish: field observations and literature reviewed. Animal Welfare, 11, 269-292

Robb, D. (2010). Factors affecting fish quality: focus on farmed salmon. EWOS Innovation. Retrieved at March $5^{\text {th }}, 2014$ from http://praise.manoa.hawaii.edu/ content/aip/Factors Affecting Fish Quality Focus on Farmed Salmon.pdf

Schmidt, M. (2013). Bacterial contamination of blood products. International Society of Blood Transfusion (ISBT) Science Series, 8(1): 177-180.

Simeonidou, S., Govans, A., \& Vareltzis, K. (1998). Quality assessment of seven Mediterranean fish species during storage on ice. Food Res.Int., 30: 479-484.

U.S. Department of Commerce. 1979. U.S.general standards for fish fillets. Fed. Regist. 44(110):3238532388. Retrieved at December $15^{\text {th }}, 2014$ from http:/ /www.seafood.nmfs.noaa.gov/pdfs/generalfillets.pdf

U.S. Food and Drug Administration. (2001). FDA and EPA safety levels in regulations and guidance. In : 
Squalen Bulletin of Marine \& Fisheries Postharvest \& Biotechnology, 9 (2), 2014, 63-74

Fish and fisheries products hazards and controls guidance. U.S. Food and Drug Administration, Washington, DC, p. 285.

Wardle, C. (1997). Welfare of Farmed Salmon and impact on Post Harvest Quality. In: Welfare of Fish at Slaughter. Ed. D. Robb. University of Bristol, United Kingdom, pp 25-30
Zampacavallo, G., Scappini, F., Mecatti, M., lurzan, F., Mosconi, G. \& Poli, B.M. (2003). Study on methods to decrease the stress at slaughter in farmed sea bass (Dicentrarchus labrax). Italian Journal of Animal Science, 2 (Suppl. 1): 616-618. 